\title{
Investigation of Antiulcer and Antioxidant Activity of Juniperus phoenicea L. (1753) Essential Oil in an Experimental Rat Model
}

\author{
Manel Jemaï Ben Ali, ${ }^{a, b}$ Fatma Guesmi, ${ }^{c}$ Abdel Halim Harrath, ${ }^{*}, d$ Saleh Alwasel, ${ }^{d}$ Amor Hedfi, ${ }^{a}$ \\ Sana Ncib, ${ }^{b}$ Ahmed Landoulsi, ${ }^{c}$ Badr Aldahmash, ${ }^{d}$ and Mossadok Ben-Attia ${ }^{a}$ \\ ${ }^{a}$ Laboratory of Environment Biomonitoring (LR01/ES14), Faculty of Sciences of Bizerte, University of Carthage; \\ Zarzouna 7021, Tunisia: ${ }^{b}$ Faculty of Sciences of Gafsa, Research Common Services Unit (RCSU); Gafsa 2112, \\ Tunisia: ${ }^{c}$ Faculty of Sciences of Bizerte, Laboratory of Biochemistry and Molecular Biology; 7021 Zarzouna, Bizerte, \\ Tunisia: and ${ }^{d}$ Department of Zoology, College of Science, King Saud University; Riyadh 11451, Saudi Arabia. \\ Received May 14, 2015; accepted August 2, 2015
}

\begin{abstract}
Juniperus phoenicea is a tree of the Cupressaceae family that is popularly known in the south of Tunisia because of its wide application in herbal medicine, including the use of its leaves to treat many diseases such as diarrhea, rheumatism, and intestinal disorders. The aim of this study was to evaluate the ulceroprotective and antioxidant activity of essential oil extracted from the leaves of $J$. phoenicea (EOJp) against hydrogen chloride (HCl)/ethanol-induced ulcers in rats. The antiulcer activities of 50,75 and $100 \mathrm{mg} / \mathrm{kg}$ body weight (b.w.) EOJp were investigated on $0.3 \mathrm{M} \mathrm{HCl} /$ ethanol-induced ulcers in rats. The essential oil yield was $0.69 \%$ with 48 compounds; $\alpha$-pinene was the principal component $(20.24 \%)$. In vivo pretreatment with EOJp given orally provided dose-dependent protection against $\mathrm{HCl} /$ ethanol-induced gastric ulcers in rats. Furthermore, pretreatment with EOJp significantly decreased malondialdehyde (MDA) content and increased the activities of superoxide dismutase (SOD), catalase (CAT) and glutathione peroxidase (GPx). The activity of the antiulcerogenic EOJp could be from synergistic antioxidant and anti-secretory effects. Oral use of EOJp has excellent preventive effects on induced gastric ulcers comparable to those of the proton pump inhibitor (PPI) omeprazole.
\end{abstract}

Key words Juniperus phoenicea; essential oil; hydrogen chloride ( $\mathrm{HCl}$ )-induced ulcer; ethanol-induced ulcer; antioxidant; antiulcer effect

Gastric ulcers are part of a chronic relapsing disease that is well known to be a polyaetiologic chronic disease. ${ }^{1)}$ The disease results from an impairment of the balance between aggressive and protective factors. ${ }^{2,3)}$ Various factors, such as stress, the use of cigarettes and alcohol, and steroidal and nonsteroidal drugs, can impair this balance, ${ }^{4,5)}$ through contributing to the loss of the mucosal epithelial lining in the gastric wall. ${ }^{6}$ Although many classic drugs are available to treat gastric ulcers, these drugs do not offer permanent treatment, and studies to discover such a treatment are on-going. The current medicinal treatment of peptic ulcers is generally based on the inhibition of gastric acid secretion by $\mathrm{H}_{2}$-blockers, antimuscarinics and omeprazole, as well as on acid-independent therapy provided by sucralfate and bismuth. ${ }^{7)}$

In recent years, herbal medicines have triumphed as a diverse popular therapy and are emerging as an alternative to the available synthetic drugs. ${ }^{8,9)}$ In fact, frequent consumption of certain fruits and vegetables has been associated with a reduced risk of developing cancer, particularly in the breast and colon. ${ }^{10,11)}$ Therefore, the development of new antiulcer drugs and the search for novel molecules has been extended to herbal drugs that offer better protection and decreased relapse. Many medicinal plants exhibit antiulcer activity and were therefore found useful for treating peptic ulcers. ${ }^{12)}$

Red juniper (Juniperus phoenicea) is widespread in Americas, Asia, Europe and Africa. It has strong resistance to wind erosion and anthropic pressure. ${ }^{13-15)}$ This species is characterized, like other junipers, by its red fruit, its bristled juvenile branched and less powerful port and the bushy appearance of its cylindrical branches, as well as by its absence in high mountains at altitudes above $2200 \mathrm{~m}$. In traditional medicines, several Juniperus species are used as remedies against many diseases. In fact, cones, twigs and especially the young shoots are administered by infusion because they have diuretic, stomach and digestive effects. ${ }^{16-20)} J$. phoenicea is also used as a decoction against diabetes, diarrhoea and rheumatism, while dried and powdered fruit can cure skin ulcerations and abscesses. ${ }^{21-23)}$

Chemical compounds are incorporated into pharmaceutical preparations, especially for antiseptic use, which is attributed to the presence of essential oils. ${ }^{24,25)}$ However, there is no information in the literature about the anti-ulcer effects of the essential oil of J. phoenicea (EOJp) nor was there any mention for other Juniperus species. Therefore, this study aims to investigate the chemical profiles and ulceroprotective and antioxidant activities of the essential oil of this plant against hydrogen chloride $(\mathrm{HCl}) /$ ethanol-induced ulcers in rats.

\section{MATERIALS AND METHODS}

Plant Material The leaves of $J$. phoenicea were collected on Mount Orbata (Jbel Orbata) near Sened (Gafsa, Tunisia). The plant material was authenticated by a Taxonomist, El Mokni Ridha (Laboratory of Botany and Plant Ecology; Faculty of Sciences of Bizerte, Bizerte, Tunisia) and the voucher specimens were deposited at the herbarium of the Laboratory of Medicinal Plants (National Agronomic Institute of Tunisia INAT, Tunisia) for future reference. No specific permission was required to collect plants from these locations, and the field studies did not involve endangered or protected species. 
Extraction and Chromatographic Analysis of EOJp The essential oil from dried powdered J. phoenicea leaves was isolated by steam distillation in a Clevenger-type apparatus according to Procedure III of the Yugoslav Pharmacopoeia IV. $^{26)}$ The essential oil yield was $0.69 \%$ (w/w). Freshly isolated essential oil was a yellow liquid that has an intense, necrotic odour.

The GC-MS analysis of the essential oil from leaves of $J$. phoenicea were performed using a Varian GC-MS (GC Varian CP 3800; MS Varian Saturn 2200) equipped with a VF-5 ms fused silica capillary column $(30 \times 0.25$ i.d., film thickness $0.25 \mu \mathrm{m})$. An electron ionization system with ionization energy of $70 \mathrm{eV}$ was used for GC-MS. Inert helium gas was used as a carrier gas at a constant flow rate of $1 \mathrm{~mL} / \mathrm{min}$. Mass transfer line and injector temperature were set at $250^{\circ} \mathrm{C}$. In fact, the oven temperature was programmed from 50 to $150^{\circ} \mathrm{C}$ at $10^{\circ} \mathrm{C} / \mathrm{min}$, then held isothermal for $6 \mathrm{~min}$ and finally raised to $250^{\circ} \mathrm{C}$ at $10^{\circ} \mathrm{C} / \mathrm{min}$. Samples $(1 \mu \mathrm{L}$ of $J$. phoenicea essential oil diluted in hexane $10 \%$ ) were manually injected in the splitless mode and the relative percentage of the essential oil constituents was expressed as percentage by peak area normalisation. $^{27)}$

Identification of chemical compounds of the essential oil was based on GC retention time on VF-5 capillary column. Varian Workstation software was used in computer matching of mass spectra with those of standards.

Preparation of Drug Solution To prepare the appropriate stock solution of the drug, i.e., $50 \mathrm{mg} / \mathrm{mL}, 75 \mathrm{mg} / \mathrm{mL}$ and $100 \mathrm{mg} / \mathrm{mL}, 100 \mathrm{~g}$ of the air dried leaves of $J$. phoenicea were steam distilled for $3 \mathrm{~h}$. For the pharmacological tests performed here, the complete essential oil was emulsified in vehicle $(0.1 \%$ Tween 80 aqueous solution) before it was administered to the animals. The doses were orally administered by selecting the appropriate concentration of the stock solution. After dissolved in vehicle, omeprazole has been given orally to the reference control group (6 rats) in doses of $20 \mathrm{mg}$ / kg body weight.

Effect of EOJp on $\mathrm{HCl} /$ Ethanol-Induced Ulcers in Rats Effect of orally administered essential oil of $J$. EOJp on $\mathrm{HCl} /$ ethanol $(60: 40,15 \mathrm{~N})$-induced ulcers in rats were investigated.

Animals

Adult male Wistar rats $(n=60)$, weighing $170-190 \mathrm{~g}$, were cared for in compliance with the code of practice for the care and use of animals for scientific purposes. Approval for these experiments was obtained from the Medical Ethical Committee for the Care and Use of Laboratory Animals of Pasteur Institute of Tunis, Tunisia (approval number: LNFP/Pro 152012).

Before any procedures were performed, all animals were kept for two weeks under the same laboratory conditions (temperature of $25 \pm 2{ }^{\circ} \mathrm{C}$ and relative humidity of $70 \pm 4 \%$ ). They were housed in polypropylene cages under pathogen free, uniform conditions of light and dark cycles ( $12 \mathrm{~h}$ each), and received a nutritionally standard diet (SICO, Sfax, Tunisia) and tap water.

Acute Toxicity of EOJp

A total of 24 rats were randomly divided into four groups ( $n=6 /$ group). The first group served as a normal control group (C). Groups two (D1), three (D2) and four (D3) were treated with EOJp dissolved in a $0.1 \%$ tween, $80 \%$ aqueous solution at dose levels of $150,200,250 \mathrm{mg} / \mathrm{kg}$, respectively. All animals were observed for toxic symptoms and mortality for $72 \mathrm{~h} .{ }^{28)}$

Administration of EOJp on $\mathrm{HCl} /$ Ethanol-Induced Ulcers in Rats

A total of 36 rats were divided into six treatment groups $(n=6)$ and fasted for $24 \mathrm{~h}$ prior treatment; water was allowed ad libitum. The treatment of these groups was performed in two steps. First, the groups were treated with vehicle, EOJp dissolved in $0.1 \%$ tween 80 aqueous solutions or omeprazole (Omp) in distilled water. Omeprazole was used as a standard antiulcer drug, which acts as a gastric anti-acid output. ${ }^{29)}$ The group (C) was kept as a control group without any treatment, while all other groups were fasted for $24 \mathrm{~h}$ and administered an oral dose of $0.5 \mathrm{~mL}$ of vehicle $(0.1 \%$ tween 80 aqueous solution). One hour after the first treatment, the mice were treated with $80 \mathrm{mg} / \mathrm{mL}$ of a solution containing $0.3 \mathrm{M} \mathrm{HCl} / \mathrm{ethanol}$ $(60: 40,15 \mathrm{~N})$. One group $(\mathrm{EtHCl})$ received a solution of $\mathrm{HCl} /$ ethanol, $(60: 40,15 \mathrm{~N})$ alone. One group (Omp) was treated with omeprazole (20 mg/kg/body weight (b.w.)) and groups G1, G2, and G3 were treated with EOJp at the doses of 50, 75 and $100 \mathrm{mg} / \mathrm{kg} /$ b.w., respectively, dissolved in a $0.1 \%$ tween $80 \%$ aqueous solution (Table 1).

The animals were sacrificed under ether anaesthesia $1 \mathrm{~h}$ after the mice were treated with $\mathrm{HCl} /$ ethanol, and the stomachs were excised and inflated with saline injection $(2 \mathrm{~mL})$ to determine the ulcer index. Throughout the experiments, the stomachs were excised and photographed. They were then opened along the greater curvature; the gastric juice and mucus covering each stomach were then carefully collected into clean tubes. The samples were analysed for the gastric liquid volume, $\mathrm{pH}$ value, and mucus weight. Each stomach was then rinsed with saline solution $(0.9 \%)$ and photographed, and the extent of the lesions were measured $\left(\mathrm{mm}^{2}\right)$ and taken as the ulcer index according to the method of Khan. ${ }^{30)}$ All animals were treated humanely and all experiments were performed in the morning and in accordance with the guidelines provided by the Institutional Animal Ethics Committee.

Macroscopic Gastric Lesion Evaluation

The gastric mucosa of each rodent was gently scraped using a glass slide, and the obtained mucus was weighed using a precision electronic balance. ${ }^{31)}$ After washing with normal

Table 1. The Experimental Design and Specifications

\begin{tabular}{lccc}
\hline \hline $\begin{array}{l}\text { Groups } \\
\text { number }\end{array}$ & Description & Pre-treatment & Treatment \\
\hline C & Control group & Control without any treatment & $(-)$ \\
EtHCl & Ulcer control group & Half milliliter of vehicle $(0.1 \%$ tween 80 aqueous solution) & $(80 \mathrm{mg} / \mathrm{mL}) \mathrm{HCl} / \mathrm{ethanol}$ \\
Omp & Reference control group & Omeprazole $20 \mathrm{mg} / \mathrm{kg}$ & $(80 \mathrm{mg} / \mathrm{mL}) \mathrm{HCl} / \mathrm{ethanol}$ \\
G1 & Experimental group 1 & Complex $50 \mathrm{mg} / \mathrm{kg}$ & $(80 \mathrm{mg} / \mathrm{mL}) \mathrm{HCl} / \mathrm{ethanol}$ \\
G2 & Experimental group 2 & Complex $75 \mathrm{mg} / \mathrm{kg}$ & $(80 \mathrm{mg} / \mathrm{mL}) \mathrm{HCl} / \mathrm{ethanol}$ \\
G3 & Experimental group 3 & Complex $100 \mathrm{mg} / \mathrm{kg}$ & $(80 \mathrm{mg} / \mathrm{mL}) \mathrm{HCl} / \mathrm{ethanol}$ \\
\hline
\end{tabular}


saline, gastric lesions were quantified and ulcers were scored according to the method used by Dashputre and Naikwade. ${ }^{32}$

The ulcer scores were as follows:

- 0: normal coloured stomach.

- 0.5: red coloration.

- 1: spot ulcers.

1.5: haemorrhagic streak.

- 2: deep ulcers.

- 3: perforation.

The mucosal lesion area $\left(\mathrm{mm}^{2}\right)$ was measured by planimetry using a transparent grid. The ulcer index (UI) for each rat was taken as the mean lesion area $\left(\mathrm{mm}^{2}\right)$.

The percentage of ulcer inhibition was determined as follows:

$\%$ inhibition of ulceration

$$
=\frac{(\text { Ulcer index EtHCl }- \text { Ulcer index treated })}{\text { Ulcer index EtHCl }} \times 100
$$

Where $\mathrm{UI}_{\mathrm{EtHCl}}$ is the ulcer index of the rats treated with $\mathrm{HCl} /$ ethanol, $(60: 40,15 \mathrm{~N})$ and $\mathrm{Ui}_{\text {treated }}$ is the ulcer index of the rats treated with EOJp or Omp and $\mathrm{HCl} /$ ethanol $(60: 40,15 \mathrm{~N})$.

Assessment of Oxidative Stress in Tissue After the macroscopic analyses, the gastroprotective effect of EOJp was assessed from the malondialdehyde (MDA) and reduced glutathione (GSH) as well as the activities of enzyme antioxidants the super oxide dismutase (SOD), catalase (CAT), glutathione peroxidase (GPx) and glutathione- $S$-transferase (GST) in gastric tissues.

Preparation of Homogenate

The stomach tissues were grinded with liquid nitrogen in a mortar. The grinded tissues were weighed and homogenized with $4.5 \mathrm{~mL}$ of buffer solution of potassium phosphate $(\mathrm{pH}$ 7.4). The mixtures were homogenized on ice, using an ultraturrax, for $15 \mathrm{~min}$; then, the mixtures were filtered and centrifuged at $4^{\circ} \mathrm{C}$. The supernatant were used to determine the enzymatic activities and MDA assays.

Estimation of Protein

The protein content of the gastric tissue was determined by the Folin Lowry Method using bovine serum albumin as a standard. ${ }^{33)}$ Reduced glutathione GSH was estimated by the method indicated by Sedlak and Lindsay. ${ }^{34)}$ The GPx activity was determined according to the method described by Sazuka et $\left.a l .{ }^{35}\right)$ The SOD activity was estimated according to the method described by Misra and Fridovitch. ${ }^{36}$ ) The CAT activity was measured according to a report by Aebi. ${ }^{37)}$ The GST activity was assayed with the method according to Habig et $a{ }^{38)}$ by adding 1-chloro-2,4-dinitrobenzene (CDNB). The lipid peroxide content in gastric tissues was determined by thiobarbituric acid reaction as described by in Ohkawa et al. ${ }^{39)}$ The lipid peroxide concentration was expressed as the nmol $\mathrm{MDA} / \mathrm{mg}$ protein.

Histological Studies After digital pictures of each stomach were obtained, the tissues were immersed for $48 \mathrm{~h}$ at $4^{\circ} \mathrm{C}$ in the fixative solution $(10 \%$ formaldehyde, in phosphate buffer, $\mathrm{pH}$ 7.6). For histological assessment, sections were obtained at intervals of $5 \mu \mathrm{m}$ and stained in haematoxylin-eosin solution (H\&E). Tissue preparations were observed and microphotographed under a light Leica DM 2500 microscope.

Statistical Analysis A descriptive statistics using a software program SPSS 18.0 were used to describe the data, which were presented as mean \pm standard deviation (S.D.). Data obtained were initially examined to confirm normal distribution and homogeneity of variance. Statistical analysis was performed using one-way ANOVA, followed by Dunnett's test, and differences between treatments were considered significant for $p<0.05$.

Table 2. Chemical Composition of Essential Oils Extracted from $J$. phoenicea Harvested in Southern Tunisia Using Analysis by GC-MS

\begin{tabular}{|c|c|c|}
\hline Composants & Amount & RI \\
\hline Androst-4-en-3-one & 0.215 & 708 \\
\hline Hexadecanoic acid & 0.587 & 717 \\
\hline$\delta$-Cadinene & 2.944 & 727 \\
\hline Podocarp-7-en-3-one & 0.289 & 730 \\
\hline Caryophyllene oxide & 0.106 & 732 \\
\hline$\beta$-Elemene & 2.152 & 733 \\
\hline 1,5,5-Trimethyl-6-methylene & 4.702 & 745 \\
\hline Androstan-3-ol & 0.016 & 750 \\
\hline Retinol & 0.370 & 753 \\
\hline Octadecanoic acid & 0.248 & 757 \\
\hline Ledene alcohol & 0.237 & 758 \\
\hline Bornyl chloride & 0.123 & 759 \\
\hline Aristolen epoxide & 0.245 & 768 \\
\hline 1-Naphthalenol & 0.885 & 771 \\
\hline Terpinolene & 4.227 & 773 \\
\hline Tricyclene & 0.357 & 776 \\
\hline Longifolene-(V4) & 2.880 & 783 \\
\hline Eucayptol & 0.403 & 787 \\
\hline$\tau$-Muurolol & 0.805 & 791 \\
\hline Murolan & 0.119 & 792 \\
\hline Himachala-2,4-diene & 0.141 & 796 \\
\hline Cyclohexane & 3.332 & 802 \\
\hline Humulane-1,6-dien-3-ol & 0.373 & 803 \\
\hline$\delta$ - Silienne & 0.010 & 805 \\
\hline 2,3-Dihydroxydroxypropyl elaidate & 0.411 & 808 \\
\hline$p$-Cymène & 2.001 & 814 \\
\hline Cubenol & 0.486 & 816 \\
\hline 2-Cyclohexen-1-ol & 0.151 & 825 \\
\hline Bornyl acetate & 0.131 & 827 \\
\hline D-Limonene & 0.440 & 828 \\
\hline $1 R, 4 S, 7 S, 11 R-2,2,4,8$-Tetrame & 3.791 & 831 \\
\hline Santolina triene & 0.265 & 836 \\
\hline Isopulegol acetate & 0.337 & 842 \\
\hline Bicyclosesquiphellandrene & 1.770 & 845 \\
\hline Cyclohexene & 1.024 & 846 \\
\hline $1,3,8-p$-Menthatriene & 0.039 & 847 \\
\hline Azulene & 3.366 & 849 \\
\hline$\alpha$-Pinene & 20.245 & 851 \\
\hline Camphene & 0.256 & 852 \\
\hline Ylangene & 0.021 & 860 \\
\hline Myrcene & 3.253 & 861 \\
\hline$\alpha$-Cubebene & 0.253 & 862 \\
\hline trans-Oxyde de linalool & 3.727 & 865 \\
\hline Copaene & 0.973 & 870 \\
\hline$\beta$-Pinene & 5.683 & 880 \\
\hline Naphtalene & 6.659 & 885 \\
\hline 3-Carene & 0.091 & 887 \\
\hline Thujopsene & 0.330 & 896 \\
\hline
\end{tabular}

$\mathrm{RI}=$ retention index 


\section{RESULTS}

Chemical Compositions of EOJp The essential oil yield of $J$. phoenicea from Gafsa is $0.69 \%$, as illustrated in Table 2. It mainly consists of $\alpha$-pinene $(20.24 \%)$, which is accompanied by naphthalene $(6.65 \%)$ of $\beta$-pinene $(5.68 \%)$, terpinolene (4.22\%), linalool (3.72\%), myrcene (3.25\%), $p$-cymene $(2.00 \%)$ and bicyclosesphellandrene (1.77\%).

Effects of EOJp on $\mathrm{HCl} /$ Ethanol-Induced Ulcers in Rats In the acute toxicity study, no deaths or toxic symptoms were observed during the test period. As a part of this pharmacological study, EOJp was investigated for its acute and general toxicity in rodents. It's interesting to note that the equilibrium between the therapeutic versus toxicological effects of a drug is a vital parameter in assessing its applicability in relation to pharmacological action. ${ }^{40)}$ None of the rats (D1, D2 and D3) experienced any toxicity or mortality, and there were no abnormal physiological or behavioural changes, nor alterations in the body weight, at any time during the $14 \mathrm{~d}$ of observation (Fig. 1).

EOJp treatment $(50,75$ and $100 \mathrm{mg} / \mathrm{kg}$ b.w.) caused a dose-dependent reduction in the $\mathrm{HCl} /$ ethanol-induced gastric lesions, decreasing the ulcer index and percentage of inhibition, especially at doses of $100 \mathrm{mg} / \mathrm{kg}$ for G3 rats $(98.94 \%)$ (Table 3). In this study, omeprazole protected the gastric mucosa against $\mathrm{HCl} /$ ethanol-induced ulceration in the Omp group $(66.35 \%)$.

The results of histological observation of EOJp on gastric ulcers induced by the $\mathrm{HCl} /$ ethanol solution are shown in Fig. 2. In fact, there were severe injuries in the gastric mucosa (haemorrhagic necrosis of the gastric mucosa) of the EtHCl group (Figs. 2c, d) compared to the control group (Figs. 2a, b). Exfoliation and epithelial oedema of the submucosal layer with deformed glands have also been observed (Figs. 2c, d) whereas moderate injuries were observed in the gastric mucosa. Stomach of rats that were pretreated with omeprazole $(20 \mathrm{mg} / \mathrm{kg})$ (Figs. 2e, f). However, stomach of G1 rats that were pretreated with EOJp $(50 \mathrm{mg} / \mathrm{kg}$ ) (Figs. $2 \mathrm{~g}$, h) has shown minor injuries in their gastric mucosa (Figs. $2 \mathrm{~g}$, h) whereas stomach of G2 rats that were pretreated with EOJp $(75 \mathrm{mg} / \mathrm{kg})$ has shown a very mild or even the absence of injury in the gastric mucosa (Figs. 2i, j). No injuries have been observed in the gastric mucosa of the rats G3 stomach that were pretreated with EOJp (100 mg/kg) (Figs. 2k, 1).

The gastric $\mathrm{HCl} /$ ethanol toxicity results in macroscopic redness of the mucous membrane; haemorrhagic lesions and a significant reduction in the mucus quantity were observed. The acidity of the gastric content in experimental animals pre-treated with EOJp (G1, G2 and G3) was significantly decreased compared to that of the ulcer control group $\mathrm{EtHCl}$ $(p<0.05)$. The mucus production of gastric mucosa also increased significantly $(p<0.05)$ in G2 and G3 rats that were treated with 75 and $100 \mathrm{mg} / \mathrm{kg}$, respectively, compared to the ulcer control group EtHCl (Table 3). The EtHCl group received $\mathrm{HCl} /$ ethanol $(80 \mathrm{mg} / \mathrm{mL})$ and had a low level of mucus $(91.06 \pm 0.80 \mathrm{mg}$ ), which is contrary to the G1 and G2 groups (having received 50 and $75 \mathrm{mg} / \mathrm{kg}$ of EOJp, respectively) that in turn had secretion that was similar to that of the control C group. The G3 group has the highest level of secreted mucus $(141.16 \pm 0.99 \mathrm{mg})$ and lowest ulcer index $\left(0.23 \pm 0.21 \mathrm{~mm}^{2}\right)$ (Table 3).

Pre-treatment of G2 and G3 groups of rats with EOJp (75 and $100 \mathrm{mg} / \mathrm{kg}$, respectively) significantly induced positive changes (Fig. 2). The stomachs of all rats treated with a higher dose of EOJp $(100 \mathrm{mg} / \mathrm{kg})$ revealed only slight congestion; otherwise, the shape of the stomach was normal. There was a clear change in the gross appearance of the gastric mucosa compared to the group that was treated acidified EtHCl. Furthermore, administering EOJp to rats reduced the gastric ulceration induced by acidified ethanol.

Biochemical Analysis The levels of lipid peroxidation products and GSH and enzymatic antioxidant activity in the gastric mucosa are shown in Table 4 . We observed that the ethanol intoxication/ $\mathrm{HCl}(60: 40,15 \mathrm{~N})$ significantly decreased $(p<0.01)$ the rate of antioxidants, SOD, CAT, GPx and GSH, and increased the MDA levels, compared to control rats (C). Comparing pre-treating rats with omeprazole $(20 \mathrm{mg} / \mathrm{kg}$ b.w.) (Omp) and EOJp, the analysis of the homogenate groups (50, 75 and $100 \mathrm{mg} / \mathrm{kg}$ b.w.) showed that the level of lipid peroxidation had a clear, significant reduction in the G1, G2 and G3 groups compared to that of $\mathrm{EtHCl}$. Furthermore, there was improvement (G3) compared to the control group C and Omp group. Moreover, we observed a significant increase in the GSH levels and antioxidant enzymes activities. Therefore, the MDA levels decreased compared to the $\mathrm{EtHCl}$ group, while the SOD, GSH, GPx, GST and CAT levels were increased (Table 4).

\section{DISCUSSION}

The chemical composition of the essential oil of red juniper has been studied in various regions, such as Morocco, ${ }^{41,42)}$

Table 3. Measurement of the Total Number of Ulcers, Ulcer Index, Inhibition Percentage, Mucus and pH

\begin{tabular}{|c|c|c|c|c|c|}
\hline Groups & $\mathrm{pH}$ & Mucus weight $(\mathrm{mg})(n=6)$ & $\begin{array}{l}\text { Total no. of ulcers } \\
(\text { mean } \pm \text { S.D. })(n=6)\end{array}$ & Ulcer index $\left(\mathrm{mm}^{2}\right)(n=6)$ & $\%$ Ulcer inhibition \\
\hline $\mathrm{C}$ & $6.28 \pm 0.37^{\boxplus c}$ & $127.92 \pm 0.74$ & - & - & - \\
\hline $\mathrm{EtHCl}$ & $2.61 \pm 0.14 * * * \mathrm{c}$ & $90.12 \pm 0.76^{* * * c}$ & $14.83 \pm 0.75 * * * \mathrm{c}$ & $22.36 \pm 0.64 * * * \mathrm{c}$ & - \\
\hline Omp & $4.36 \pm 0.77 * * * \square$ & $128.41 \pm 1.44$ & $4.5 \pm 0.54 * * * \square$ & $7.52 \pm 0.55^{* * * *}$ & $66.35^{* * * \bullet}$ \\
\hline G1 & $4.55 \pm 0.54 * * * \square$ & $106.16 \pm 1.47 * * *$ m & $4.16 \pm 0.75 * * * \square$ & $4.59 \pm 0.9 * * * \varpi \mathrm{c}$ & $79.45^{* * * \bullet c}$ \\
\hline G2 & $4.93 \pm 0.1 * * * \mathbf{m c}_{\mathrm{c}}$ & $125.66 \pm 0.81 * \mathbf{\square c}_{\mathrm{c}}$ & $0.83 \pm 0.75^{\mathrm{c}}$ & $1.24 \pm 0.53 * * * \mathbf{m c}_{\mathrm{c}}$ & $94.31 * * * \bullet c$ \\
\hline G3 & $5.05 \pm 0.08 * * * \square \mathrm{c}$ & $141.16 \pm 0.99 * * *$ c & $0.28 \pm 0.21^{\mathrm{c}}$ & $0.23 \pm 0.21{ }^{m}$ & $98.94 * * * \bullet c$ \\
\hline
\end{tabular}

All values are expressed as mean \pm S.D. of measurement of 6 rats in each group. Mean difference is significant at the $p<0.05$ level (ANOVA followed by HSD Tukey test). ${ }^{*} p<0.05$ compared with respective control group. ${ }^{* *} p<0.01$ compared with respective control group. ${ }^{* * *} p<0.001$ compared with respective control group. ${ }^{*}<<0.05$ compared with respective EtHCl group. ${ }^{\bullet} p<0.01$ compared with respective EtHCl group. ${ }_{p}<0.001$ compared with respective EtHCl group. ${ }^{a} p<0.05$ compared with respective Omp group. ${ }^{\mathrm{b}} p<0.01$ compared with respective Omp group. ${ }^{\mathrm{c}} p<0.001$ compared with respective Omp group. 


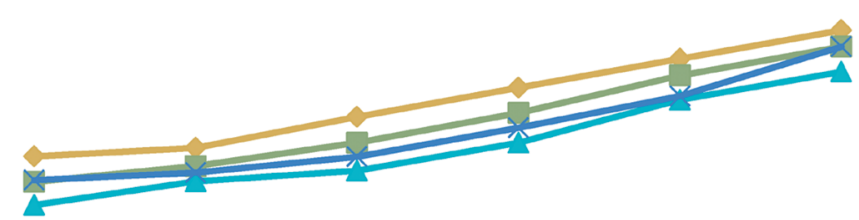

\begin{tabular}{|c|c|c|c|c|c|}
\hline 1 & 3 & 6 & 10 & 12 & 14 \\
\hline
\end{tabular}

Fig. 1. Body Weight Gain in Rats Treated Orally with Vehicle (EOJp: 50, 75 and $100 \mathrm{mg} / \mathrm{kg}$ ) for $14 \mathrm{~d}$ The results are given as the mean \pm S.E.M., $n=6$. ANOVA, $p<0.05$ between groups in the same day.
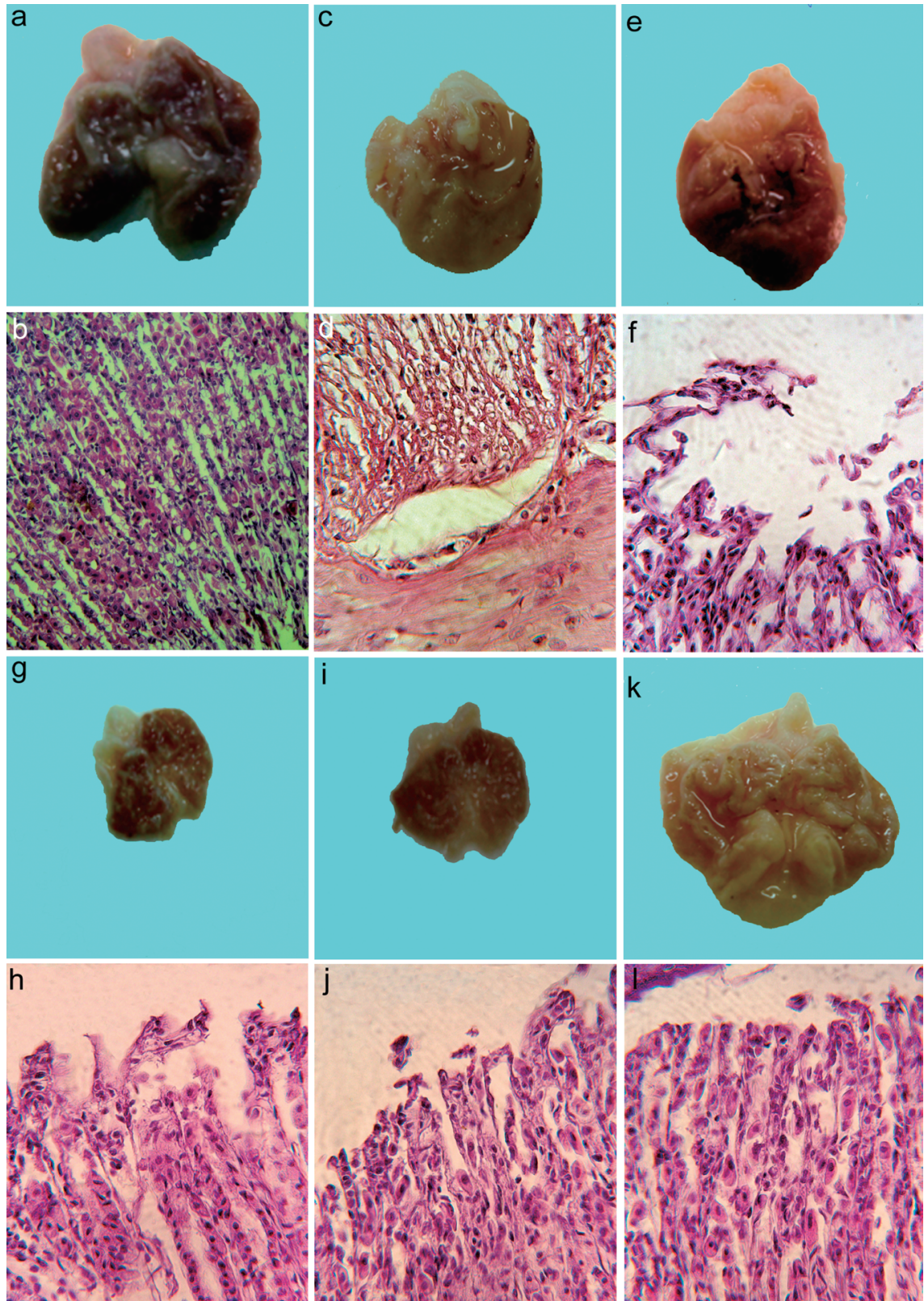

Fig. 2. Photographs of the Whole, Dissected and Sectioned Stomachs from Rats That Underwent Ethanol-Induced Gastric Ulcers

Sections were stained with haematoxylin and eosin. Magnifications: b and $\mathrm{d}(\times 20) ; \mathrm{f}, \mathrm{h}, \mathrm{j}$ and $\mathrm{l}:(\times 40)$; a, c, e, g, i and k: magnifications are not available since the photos of the stomach have been taken using a Sony-Cybershot DSC-W350 digital camera. a, b: Control group of a normal stomach. c, d: The EtHCl group was negative for stomach findings; there were severe injuries in the gastric mucosa (haemorrhagic necrosis of the gastric mucosa). Also shown are micrograph exfoliation and epithelial oedema (ede) of the submucosal layer with deformed glands. e, f: Stomach of rats that were pretreated with omeprazole $(20 \mathrm{mg} / \mathrm{kg})$, and moderate injury was observed in the gastric mucosa. $\mathbf{g}, \mathbf{h}$ : stomach of G1 rats that were pretreated with EOJp ( $50 \mathrm{mg} / \mathrm{kg}$ ); minor injuries can be observed in the gastric mucosa. $\mathbf{i}$, j: stomach of G2 rats that were pretreated with EOJp $(75 \mathrm{mg} / \mathrm{kg})$; very mild or even the absence of injury can be observed in the gastric mucosa. G3 (k, l) stomach of rats that were pretreated with EOJp $(100 \mathrm{mg} / \mathrm{kg})$; instead of flattening the stomach, no injury could be observed in the gastric mucosa. 
Table 4. Measurement of the Gastric Malondialdehyde (MDA), Superoxide Dismutase (SOD), Catalase (CAT), Reduced Glutathione (GSH), Glutathione Peroxidase (GPx) and Glutathione Transferase (GST) in HCl/Ethanol Ulcerated Rats

\begin{tabular}{|c|c|c|c|c|c|c|c|}
\hline Groups & $\begin{array}{c}\text { Lipid peroxidation } \\
\text { nmol } \mathrm{MDA} / \mathrm{mg} \\
\text { protein }\end{array}$ & $\begin{array}{c}\text { Protein } \\
\text { concentration } \\
(\mu \mathrm{g} / \mathrm{mL})\end{array}$ & $\begin{array}{c}\mathrm{GSH} \\
(\mu \mathrm{mol} / \mathrm{mg} \text { protein })\end{array}$ & $\begin{array}{c}\text { SOD } \\
\text { (U/mg protein) }\end{array}$ & $\begin{array}{c}\mathrm{CAT} \mu \mathrm{mol} \mathrm{H}_{2} \mathrm{O}_{2} \\
\text { consumed } / \mathrm{min} / \\
\text { mg protein }\end{array}$ & $\begin{array}{l}\mathrm{GPx} \mu \mathrm{mol} \mathrm{GSH} / \\
\mathrm{mg} \text { protein } / \mathrm{mL}\end{array}$ & $\begin{array}{l}\text { GST nmol of } \\
\text { CDNB conjugate } \\
\text { formed/min/ } \\
\text { mg protein }\end{array}$ \\
\hline $\mathrm{C}$ & $0.323 \pm 0.046^{\square c}$ & $20.96 \pm 0.51$ & $2.46 \pm 0.09^{\square}$ & $3.57 \pm 0.3^{\square}$ & $7.65 \pm 0.34$ & $1.96 \pm 0.05^{\mathbf{\square}}$ & $1.29 \pm 0.45^{\diamond}$ \\
\hline $\mathrm{EtHCl}$ & $0.635 \pm 0.045^{* * * c}$ & $12.01 \pm 0.30 * * * \mathrm{c}$ & $0.82 \pm 0.06^{* * * \mathrm{c}}$ & $1.82 \pm 0.12 * * * \mathrm{c}$ & $2.18 \pm 0.18^{* * * \mathrm{c}}$ & $0.94 \pm 0.06^{* * * \mathrm{c}}$ & $0.84 \pm 0.08 * \mathrm{c}$ \\
\hline Omp & $0.413 \pm 0.051 * *$ & $20.72 \pm 0.44$ & $1.94 \pm 0.06 * * * \mathbf{\square}$ & $3.32 \pm 0.34$ & $7.45 \pm 0.45^{\square}$ & $1.82 \pm 0.12^{\square}$ & $0.93 \pm 0.05$ \\
\hline G1 & $0.392 \pm 0.039^{\square}$ & $22.23 \pm 0.26 * * * \mathbf{m}_{\mathrm{c}}$ & $2.50 \pm 0.25^{\square c}$ & $4.05 \pm 0.1 * * \mathbf{c}_{\mathrm{c}}$ & $8.02 \pm 0 . .47^{\square}$ & $2.05 \pm 0.08^{\square}$ & $1.21 \pm 0.18$ \\
\hline $\mathrm{G} 2$ & $0.293 \pm 0.037^{\square}$ & $24.88 \pm 0.45 * * * \mathbf{m}_{\mathrm{c}}$ & $2.78 \pm 0.18 * * \square \mathrm{c}$ & $4.13 \pm 0.14 * * \square c$ & $8.32 \pm 0.29 * \mathbf{m}_{\mathrm{c}}$ & $2.21 \pm 0.26^{\mathrm{aa}}$ & $1.44 \pm 0.26^{\bullet c}$ \\
\hline G3 & $0.232 \pm 0.018 * *$ 回 & $26.63 \pm 0.51 * * *$ c & $2.98 \pm 0.04 * * *=\mathrm{c}$ & $4.31 \pm 0.17 * * *=\mathrm{c}$ & $8.95 \pm 0.06 * * *=\mathrm{c}$ & $2.38 \pm 0.32 * * \square \mathrm{c}$ & $1.91 \pm 0.09 * * \square \mathrm{c}$ \\
\hline
\end{tabular}

All values are expressed as mean \pm S.D. of measurement of 6 rats in each group. Mean difference is significant at the $p<0.05$ level (ANOVA followed by HSD Tukey test). ${ }^{*} p<0.05$ compared with respective control group. ${ }^{* *} p<0.01$ compared with respective control group. $* * * p<0.001$ compared with respective control group. $p<0.05$ compared with respective EtHCl group. ${ }^{\bullet} p<0.01$ compared with respective EtHCl group. ${ }^{p}<0.001$ compared with respective EtHCl group. ${ }^{a} p<0.05$ compared with respective Omp group. ${ }^{\mathrm{b}} p<0.01$ compared with respective Omp group. ${ }^{\mathrm{c}} p<0.001$ compared with respective Omp group.

Algeria, ${ }^{43)}$ Corsica, ${ }^{44)}$ Spain, ${ }^{45)}$ Portugal, ${ }^{45,46)}$ Greece, ${ }^{45)}$ Egypt, ${ }^{47,48)}$ Saudi Arabia ${ }^{49}$ and France. ${ }^{50)}$ In Tunisia, the chemical characterization of essential oils of the aerial part of $J$. phoenicea from different regions has also been studied. ${ }^{51,52)}$ However, the chemical composition of essential oils and antioxidants in leaves as well as their healing and anti-ulcerogenic properties has not previously been studied. The essential oil yield of $J$. phoenicea from Gafsa is $0.69 \%$. It is higher than Medenine $(0.5 \%)$ (South of Tunisia) ${ }^{52)}$ and Greece $(0.21 \%)$ and is close to that of Spain $(0.66 \%) .{ }^{45)}$ The chemical composition does not differ greatly from Medenine's $J$. phoenicea essential oil (South of Tunisia), which is very rich in $\alpha$-pinene $(59.11 \%)^{52)}$ and of Greece and Spain, which are richer in myrcene (4.5 and $4.0 \%$, respectively) and $\beta$-phellandrene (3.5 and $5.9 \%$, respectively) and poor in $p$-cymene ( 0.80 and $0.40 \%$, respectively). ${ }^{45)}$

In terms of its phytochemical constituents, J. phoenicea generally contains major classes of secondary metabolites, such as flavonoids, phenolic compounds and terpenoids. These metabolites have several biological activities, such as antibacterial, anti-inflammatory, antiviral, insect repellent, sedative, flavouring and herbicide activities. ${ }^{53)}$ Under physiological conditions, mucus from goblet cells or mucocytes protects the gastric mucosa against the incisive action of hydrochloric acid and the digestive action of proteolytic enzymes in gastric juice. In fact, Ruchebuch ${ }^{54)}$ confirmed that at this level, where prostaglandins play a stimulatory role in the gastric mucus secretion, there is a feedback mechanism that inhibits the gastric acid secretion of gastrin (responsible for secretion of the hydrochloric acid via somatostatin and gastric inhibitory peptide (GIP)). As described in other studies, the oral administration of ulcerogenic agent for the control group produced clear mucosal damage, which was characterized by multiple bleeding with red stripes of different sizes along the long axis of the glandular stomach. ${ }^{55,56)}$ Acidified ethanol is an aetiological factor; its excessive ingestion gives rise to gastritis, which is characterized by oedema of the mucosa, subepithelial haemorrhage, cellular exfoliation and infiltration of inflammatory cells. ${ }^{57)}$ In histological sections, EOJp could protect the gastric tissues from $\mathrm{HCl} /$ ethanol injury by enhancing gastric mucus production, healing the ulcer craters and keeping a near normal epithelial cells arrangement.

Ulcerogenic agents, such as $\mathrm{HCl}$ and $\mathrm{EtOH}$, are responsible for damage and necrosis of the gastric mucosa and deple- tion of their defence mechanisms. ${ }^{58)}$ Of all these changes, the most prominent are increased capillary permeability and the production of free radicals, ${ }^{59)}$ which damage cell membranes, attract neutrophils and initiate inflammatory responses. ${ }^{60)}$ From histological results of the present study, we suggest that pre-treatment with EOJp inhibited leukocyte infiltration into the gastric wall thereby protecting the gastric mucosa. In fact, an erosion of the gastric epithelial cells, widening of the inter-glandular spaces and infiltration of the neutrophils in the ulcerated zones have been observed in ulcers $\mathrm{HCl} /$ ethanolinduced rats, whereas EOJp exhibited a protective effect. The activation and infiltration of neutrophils seem to be involved in the initial process that forms lesions. ${ }^{61)}$ In the same context, neutrophil accumulation in the gastric mucosa induces microcirculatory abnormalities. ${ }^{62}$ ) This is defined by the histological results of the present study, where a marked reduction of lesions in the gastric mucosa and cellular influx was observed. In fact, histological study revealed that there is erosion of the gastric epithelial cells, widening of the inter-glandular spaces and infiltration of the neutrophils in the ulcerated zones, whereas EOJp exhibited a protective effect against $\mathrm{HCl}$ /ethanol-induced ulcerogenesis in rats.

Compared to controls, the ethanol intoxication significantly decreased the SOD, CAT, GPx and GSH levels as well as increased the MDA levels. Inversely, the SOD, CAT, GPx, GST and GSH activities were significantly elevated by the administration of omeprazole and EOJp in the treated rats, suggesting the preventive effect of EOJp against ulcers induced by $\mathrm{HCl}$ / Ethanol. Omeprazole is the first of a new class of drugs that inhibit gastric secretion by altering the activity of $\mathrm{H}+/ \mathrm{K}+-$ ATPase. ${ }^{63,64)}$ On the other hand, omeprazole has been effective in reducing oxidative stress in the $\mathrm{HCl} /$ ethanol model; it is not charged and can cross cell membranes. ${ }^{63-65)}$ It accumulates in the acid space of the parietal cells because it is a weak base. It becomes a cationic thiol-reactive sulfenic acid and/or sulfenamide that binds to groups to form disulphide cysteinyl-S by acid catalysed rearrangement. ${ }^{7}$ Our results corresponded to an earlier report that showed a depletion of sulfhydryls in $\mathrm{HCl} /$ ethanol-induced gastric lesions. ${ }^{66)}$ In normal conditions, gastric cells possess a powerful antioxidant defence system, including SOD, CAT, GSH-Px and GST, which play a protective role against xenobiotics. ${ }^{67)}$ In the present study, the administration of $\mathrm{HCl} /$ ethanol significantly $(p<0.01)$ decreased the activities of SOD, CAT and GSH-Px enzymes compared 
to control rats. In contrast, pre-treatment of ethanol-ulcerated rats with EOJp preserved the activities of the aforementioned antioxidant enzymes to near normal and decreased the lipid peroxidation product (MDA) activity as dose-dependent mass production of free radicals. In fact, the increase in MDA may suggest a possible mechanism of tissue damage through reactive oxygen intermediates. ${ }^{68)}$ These free radicals are highly toxic and can cause direct damage to proteins, DNA and lipid membranes. ${ }^{69)}$ This leads to loss of the membrane fluidity and ion transport as well as impaired membrane integrity and, finally, the loss of cell functions. ${ }^{70)}$ Reduced glutathione is one of the most abundant non-enzymatic antioxidant biomolecules that is present in the tissues. ${ }^{71)}$ Its functions are to act as a substrate for GPx and GST, to remove free oxygen species, such as hydrogen peroxide $\left(\mathrm{H}_{2} \mathrm{O}_{2}\right)$ (superoxide anions and alkoxy radicals), and to maintain membrane protein thiols. ${ }^{72)}$ The non-availability of GSH decreases the activities of GSHdependent enzymes, GPx and GST, and/or renders these enzymes inactive and/or less active. ${ }^{73)}$ This study has shown that a medicinal plant probably antagonizes the aggressive factors, which play an important role in the pathogenesis of gastric ulcers, while augmenting the defensive mucosal factors that protect the gastric mucosa from injury. Similar observations were found by Guesmi et al. using essential oil of Thymys algeriensis in the treatment of gastric ulcer induced by $\mathrm{HCl}$ / ethanol. $^{74)}$

In this study, we conclude that the oral administration of the essential oil of Juniperus phoenicea has potent anti-ulcer activity, which justifies the ethnomedical claims about its significant gastroprotective effect, as evaluated by the significant antioxidant activity because it reduces the MDA level and increases the GSH, GST, GPx, CAT and SOD levels. This effect may be related to an increase in the gastric mucosal defence mechanisms. The results of our study revealed histopathological maintaining the integrity of the mucosa. As a result, the protective effect of the essential oil and its low toxicity requires further study to elucidate the mechanism of action and isolate the active principles.

Acknowledgment The authors would like to extend their sincere appreciation to the Deanship of Scientific Research at King Saud University for funding this Research group NO (RG\#164).

Conflict of Interest The authors declare no conflict of interest.

\section{REFERENCES}

1) Süleyman H, Demirezer LO, Buyukokuroglu ME, Akcay MF, Gepdiremen A, Banoglu ZN, Göçer F. Antiulcerogenic effect of Hippophae rhamnoides L. Phytother. Res., 15, 625-627 (2001).

2) Al-Howiriny $\mathrm{T}$, Alsheikh A, Alqasoumi S, Al-Yahya M, ElTahir K, Rafatullah S. Protective effect of Origanum majorana L. 'Marjoram' on various models of gastric mucosal injury in rats. $\mathrm{Am} . \mathrm{J}$. Chin. Med., 37, 531-545 (2009).

3) Zanatta F, Gandolfi RB, Lemos M, Ticona JC, Gimenez A, Clasen BK, Cechinel Filho V, de Andrade SF. Gastroprotective activity of alkaloid extract and 2-phenylquinoline obtained from the bark of Galipea longiflora Krause (Rutaceae). Chem. Biol. Interact., 180, 312-317 (2009).

4) Soll AH, Isenberg J. Peptic ulcer disease: epidemiology, pathophi- siology, clinical manifestations and diagnosis. Goldman Bennett Cecil Texbook of Medicine. (Drazen JM, Gill GN, Griggs RC, et al. eds.) 21st Ed. Saunders, Philadelphia, pp. 671-675 (2000).

5) Hooderwerf WA, Pasricha PJ. Pharmacotherapy of gastric acidity, peptic ulcers, and gastroesophageal reflux disease. Goodman and Gilman's the pharmacological basis of therapeutics. (Brunton L ed.) McGraw-Hill, New York, pp. 967-981 (2006).

6) Baghad DI, Bellabah A, Cherkaoui A, Loukili O, Chihab F. Les complications des ulcères gastro-duodénaux au cours du Ramadan. Espérance Médicale, 17, 380-383 (2010).

7) Shin JM, Sachs G, Pharmacology of proton pump inhibitors. Curr. Gastroenterol. Rep., 10, 528-534 (2008).

8) Goel RK, Sairam K. 2002. Anti-ulcer drugs from indigenous source with Emphasison musa spaientum, Tamrabhasma, Asparagus racemous and Zingiber officinale. Indian J. Pharm., 34, 100-110 (1978).

9) Ubaka MC, Ukwe VC, Okoye CT, Adibe OM. Investigation into the antiulcer activity of aqueous extract of Aspilla africana. Asian. J. Med. Sci., 2, 40-43 (2010).

10) Palmer S. Nutrition, and cancer. Prog. Food Nutr. Sci. (ISSN) 0306-0632, 9, 283-341 (1985).

11) Dinicola S, Cucina A, Antonacci D, Bizzarri M. Anticancer Effects of Grape Seed Extract on Human Cancers: A Review. J. Carcinog. \& Mutagen, 10, 2157-2518 (2014).

12) Rupesh KM, Mohamed NK, Tamizh MT, Fasalu ROM, Satya KB. A review on medicinal plants for peptic ulcer. Der Pharmacia Lettre, 3, 180-186 (2011).

13) Benabid A. Flore et écosystèmes du Maroc: évaluation et préservation de la biodiversité. Ibis Press. Paris, pp. 49-52 (2000).

14) Aafi A, Benabid A, Benrahmoune Z, Jdi E, Faiqi M, Morsli A. Les groupements végétaux du milieu dunaire de Mehdia: Etat actuel et propositions de restauration. Ann. Rech. For. Maroc., 33, 12-20 (2000).

15) Aafi A. Ecosystèmes naturels des zones semi-arides, arides et hyper-arides du Maroc. Enda Maghreb, Dakar (2003).

16) Yesilada E, Honda G, Sezik E, Tabata M, Goto K, Ikeshiro Y. Traditional medicine in Turkey. IV. Folk medicine in the Mediterranean subdivision. J. Ethnopharmacol., 39, 31-38 (1993).

17) Bellakhder J. La pharmacopée marocaine traditionnelle. Ibis Press, Paris, pp. 271-272 (1997).

18) Barrero AF, Del Moral JFQ, Herrador MM, Akssira M, Said AB, Akkad MA. Oxygenated diterpenes and other constituents from Moroccan Juniperus phoenicea and Juniperus thurifera var. Africana. Phytochemistry, 65, 2507-2515 (2004).

19) Seca AML, Silva AMS, Bazzocchi IL, Jimenaez IA. Diterpene constituents of leaves from Juniperus brevifolia. Phytochemistry, 69, 498-505 (2008).

20) Abdou H, Salah S, Raouf A, Abdel-Rahim E. Chromosomal aberrations and nucleic acids systems affected by some Egyptian medicinal plants used in treating female pregnant diabetic rats. Am. J. Mol. Bio., 1, 26-32 (2011).

21) Le Floc'h E. Contribution à une étude ethnobotanique de la flore tunisienne. Editions Ministère de l'enseignement supérieur et de la recherche scientifique. Radès ville, Tunisie: Imprimerie officielle de la République Tunisienne (1983).

22) Adams RP. Junipers of the world: the genus Juniperus. Trafford Publishing Co., Vancouver, Canada (2004).

23) Qnais EY, Abdulla YY, Abu Ghlyun P. Antidiarrheal effect of $J u$ niperus phoenicea L. leaves extract in rats. J. Biol. Sci., 8, 867-871 (2005).

24) Stassi V, Verykokidou E, Loukis A, Harvala A, Philianos S. The antimicrobial activity of the essential oils of four Juniperus species growing wild in Greece. J. Flav. Fragr, 11, 71-74 (1996).

25) Medini H, Marzouki H, Chemli R, Marongiu B, Piras A, Porcedda S, Tuveri E. Chemical characterization and evaluation of biological activity of essential oils of Juniperus phoenicea of Tunisia. J. of Essent. Oil. Bear. Plan. (ISSN) 0972-060X (2006). 
26) Jug P. IV Yugoslavian Pharmacopoeia, Pharmacopoea Jugoslavica edition quarta, vol. no. I. Belgrade, Yugoslavia: Nat. Inst. For. Hea. Prote., 126-128 (1984).

27) Adam RP. Identification of Essential Oil Components by Gas Chromatography/Quadrupole Mass Spectroscopy. Allured Publishing Corporation, Carol Stream, IL, U.S.A. (2001).

28) Malone RA. Pharmacological approaches to natural products screening and evaluation. New natural products and plant drugs with pharmacological, biological or therapeutical activity. (Warner H, Wolf P eds.) Springer-Verlag, Berlin, pp. 24-53 (1977).

29) Shaker E, Mahmoud H, Mnaa S. Anti-inflammatory and anti-ulcer activity of the extract from Alhagi maurorum (camelthorn). Food Chem. Toxicol., 48, 2785-2790 (2010).

30) Khan HA. Computer-assisted visualization and quantitation of experimental gastric lesions in rats. J. Pharmacol. Toxicol. Methods, 49, 89-95 (2004).

31) Taha MME, Salga MS, Ali HM, Abdulla MA, Abdelwahab SI, Hadi AHA, Gastroprotective activities of Turnera diffusa Willd. ex Schult. revisited: role of Arbutin. J. Ethnopharmacol., 141, 273-281 (2012).

32) Dashputre NL, Naikwade NS. Evaluation of anti-ulcer activity of methanolic extract of Abutilon indicum Linn. leaves in experimental rats. Int. J. Pharm. Sci. Drug Res., 3, 97-100 (2011).

33) Lowry OH, Rosenbrough NJ, Farr AL, Randall RJ. Protein measurement with folinphenol reagent. J. Biol. Chem., 193, 265-275 (1951).

34) Sedlak J, Lindsay RH. Estimation of total, protein-bound, and nonprotein sulfhydryl groups in tissue with Ellman's reagent. Anal. Biochem., 25, 192-205 (1968).

35) Sazuka Y, Tanizawa H, Takino Y. Effet of adriamycin on the activites of superoxide dismutase, glutathione peroxidase and catalase in tissues of mice. Jpn. J. Cancer Res., 80, 89-94 (1989).

36) Misra HP, Fridovitch I. The role of superoxide anion in the autooxidation of epinephrine and a simple assay for superoxide dismutase. J. Biol. Chem., 247, 3170-3175 (1972).

37) Aebi H. Catalase in vitro. Methods Enzymol., 105, 121-126 (1984).

38) Habig WH, Pabst MJ, Jakoby WB. Glutathione $S$-transferase: the first enzymatic step in mercapturic acid formation. J. Biol. Chem., 249, 7130-7139 (1974).

39) Ohkawa H, Ohishi N, Yagi K. Assay for lipid peroxides in animal tissue by thiobarbituric acid reaction. Anal. Biochem., 95, 351-358 (1979).

40) Loomis TA, Hayes AW. Essentials of Toxicology. 4th edition. Academic Press, Limited London (1996).

41) Mansouri N, Satrani B. Ghanmi El, Ghadraoui L, Aafi A. Étude chimique et biologique des huiles essentielles de Juniperus phoenicea ssp. lycia et Juniperus phoenicea ssp. turbinata du Maroc. Biotechnol. Agron. Soc. Environ., 15, 415-424 (2011).

42) Fouad B, Abderrahmane R, Youssef A, Rajae H, El Fels MA. Chemical composition and antibacterial activity of the essential oil of Moroccan Juniperus phoenicea. Nat. Prod. Commun., 6, 1515-1518 (2011)

43) Bekhechi C, Atik Bekkara F, Consiglio D, Bighelli A, Tomi F. Chemical variability of the essential oil of Juniperus phoenicea var. turbinata from Algeria. Chem. Biodivers., 9, 2742-2753 (2012).

44) Rezzi S, Cavaleiro C, Bighelli A, Salgueiro L, da Cunha AP, Casanova J. Intraspecific chemical variability of the leaf essential oil of Juniperus phoenicea ssp. turbinata from Corsica. Biochem. Syst. Ecol., 29, 179-188 (2001).

45) Adams RP, Barrero AF, Lara A. Comparisons of the leaf essential oils of Juniperus phoenicea, J. phoenicea ssp. eu-mediterranea Lebr. \& Thiv. and J. phoenicea var. turbinata (Guss) Parl. J. Essent. Oil. Res, 8, 367-371 (1996).

46) Cavaleiro C, Rezzib S, Salgueiroa L, Bighellib A, Casanovab J, Da Cunha AP. Infraspecific chemical variability of the leaf essential oil of Juniperus phoenicea var. turbinata from Portugal. Biochem. Syst.
Ecol., 29, 1175-1183 (2001).

47) Afifi MS, El Sharkawy SH, Maatoog GT. Sohly MEl, Rosazza JPN. Essential oils of Thuja occidentalis, Thuja orientalis, Cupressus sempervirens and Juniperus phoenicea from the Mansoura. J. Pharm. Sci., 8, 37-46 (1992).

48) El-Sawi SA, Motawae HM, Ali AM. Chemical composition, cytotoxic activity and antimicrobial activity of essential oils of leaves and berries of Juniperus phoenicea L. grown in Egypt. Afr. J. Tradit. Complement. Altern. Medicines, 4, 417-426 (2007).

49) Dawidar AM, Ezmirly ST, Abdel-Mogib M. Sesquiterpenes and diterpenes from Juniperus phoenicea L. Pharma, 46, 472-473 (1991).

50) Tabacki C, LaPorte Y. Diterpenes of Juniperus phoenicea. Major constituents. Phytochemistry, 10, 2147-2153 (1971).

51) Akrout A, Chemli R, Chreif I, Hammami M. Etude des huiles essentielles de quelques plantes pastorales de la région de Matmata (Tunisie). J. Flav. Fragr, 16, 337-339 (2001).

52) Bouzouita N, Kachouri F, Ben Halima M, Chaabouni MM. Composition chimique et activités antioxydante, antimicrobienne et insecticide de l'huile essentielle de Juniperus phoenicea. J. Soc. Chim. Tunis, 10, 119-125 (2008).

53) Duke JA. Phytochemical Database. USDA-ARS-NGRL (eds.), Beltville Agricultural Research Center, Belstville, Maryland (1998).

54) Ruchebuch Y. Physiologie, pharmacologie, thérapeutique animales. $2^{\text {ième }}$ edition, Maloine, Paris, p. 611 (1981).

55) Shay H, Komaov SA, Fels SS, Meranze D, Grunstein M, Siplet H. A simple method for the uniform production of gastric ulceration in the rat. Gastroenterology, 5, 43-61 (1945).

56) Yassir M, Al Mulla HYM, Najim RA, Farjou IB. A new in vitro model for ethanol induced gastric mucosal damage. Jpn. J. Pharmacol. Toxicol. Methodol., 41, 167-172 (1999).

57) Kvietys PR, Beveleign T. Role of methrophils and xanthine oxidase derived radicals in methanol-induced injury. Gastroenterology, $\mathbf{9 8}$, 909-920 (1990).

58) Kinoshita M, Kume E, Tamaki H. Roles of prostaglandins, nitric oxide and the capsaicin-sensitive sensory nerves in gastroprotection produced by ecabet sodium. J. Pharmacol. Exp. Ther., 275, 494-501 (1995).

59) Ueda S, Yoshikawa $T$, Takahashi S, Ichikawa H, Yasuda M, Oyamada H, Tanigawa T, Sugino S, Kondo M. Role of free radicals and lipid peroxidation in gastric mucosal injury induced by ischemiareperfusion in rats. Scand. J. Gastroenterol., 24 (s162), 55-58 (1989).

60) Ribeiro M, Yoshida WB. Reperfusion injury after intestinal ischemia: pathophysiology and experimental models. J. Vasc. Bras., 4, 183-194 (2005)

61) Ibrahim IAA, Qader SW, Abdullah MA, Nimir AR, Abdelwahab SI. AL-Bayaty FH. Effect of Pithecellobium jiringa ethanol extract against ethanol-induced gastric mucosal injuries in Sprague Dawley rats. Molecule, 17, 2796-2811 (2012).

62) Bou-Abboud CF, Wayland H, Panlsen G, Guth PH. Microcirculatory stasis precedes tissue necrosis in ethanol-induced gastric mucosal injury in rat. Dig. Dis. Sci., 33, 872-877 (1988).

63) Sachs G. The parietal cell as a therapeutic target. Scand. J. Gastroenterol., 21 (s118), 1-10 (1986).

64) Wallmark B. Omeprazole: mode of action and effect on acid secretion in animals. Scand. J. Gastroenterol., 24 (s166), 12-18 (1989).

65) Paul N, Maton MD. Omeprazole. Drug Ther., 324, 965-975 (1991).

66) La Casa C, Villegas I, Alarcón de la Lastra C, Motilva V, Martín Calero MJ. Evidence for protective and antioxidant properties of rutin, a natural flavone, against ethanol-induced gastric lesions. $J$. Ethnopharmacol., 71, 45-53 (2000).

67) Çehirli Ö, Tatlidede E, Yuksel M, Erzik C, Çetinel S, Yeğen BC, Çener G. Antioxidant effect of alpha-lipoic acid against ethanolinduced gastric mucosal erosion in rats. Pharmacology, 81, 173-180 (2008).

68) Bonnes-Taourel D, Guerin MC, Torreilles J. Is malondialdehyde a 
valuable indicator of lipid peroxidation? Biochem. Pharmacol., 44, 985-988 (1992).

69) Huet O, Duranteau J. Dysfonction endothéliale: rôle des radicaux libres and oxidative mechanisms of different forms of Chromium. Toxicology, 180, 5-22 (2008).

70) Tandon R, Khanna HD, Dorababu M, Goel RK. Oxidative stress and antioxidants status in peptic ulcer and gastric carcinoma. Indian J. Physiol. Pharmacol., 48, 115-118 (2004).

71) Meister A. New aspects of glutathione biochemistry and transport selective alteration of glutathione metabolism. Nutr. Rev., 42, 397-
410 (1984).

72) Mizui T, Doteuchi M. Effect of polyamines on acidified ethanolinduced gastric lesions in rats. Jpn. J. Pharmacol., 33, 939-945 (1983).

73) Fridovich I. The biology of oxygen radicals. Science, 201, 875-880 (1978).

74) Guesmi F, Ben Ali M, Barkaoui T, Tahri W, Mejri M, Ben-Attia M, Bellamine H, Landoulsi A. Effects of Thymus hirtus sp. algeriensis Boiss. et Reut. (Lamiaceae) essential oil on healing gastric ulcers according to sex. Lipids Health Dis., 13, 138 (2014). 